IBIMA Publishing

Journal of Marketing Research \& Case Studies

http://www.ibimapublishing.com/journals/JMRCS/jmrcs.html

Vol. 2015 (2015), Article ID 377050, 12 pages

DOI: $10.5171 / 2015.377050$

Research Article

\title{
The Real Stimuli in Popular Stores
}

\author{
Maher Taib Toukabri \\ College of Business Administration, Arar, Northern Borders University. Saudi Arabia
}

Received date: 2 October 2014; Accepted date: 16 December 2014; Published date: 15 April 2015

Correspondence should be addressed to: Maher Toukabri; maher_toukabri@yahoo.fr

Copyright (C 2015. Maher Taib Toukabri. Distributed under Creative Commons CC-BY 4.0

\begin{abstract}
The popular store has a wide and shallow assortment of items with high turnover and low margins rate. This kind of point of sale is designed for poor consumers. It was in 1873 the first trial of implantation of a popular magazine by Frank Winfield Woolworth in Watertown, in the American state of Arial. After six years, this idea has had success in Lancaster, Pennsylvania. However, this huge potential has not elapsed as much ink as it deserves. In addition, the marketers claim that the poor are affected only by the price, while atmospheric factors will not have a strong interest in the eyes of this target. This paper aims to identify closely the impact factors on behavioral intention in the popular store.
\end{abstract}

Keywords: popular store, atmospheric, price consciousness and behavioral intention

\section{Introduction}

Interest in the phenomenon of poverty is not only concerned with economists and sociologists but also with marketers. However, the precariousness of consumers has not passed as much ink as it deserves from marketers, despite the shop potential of the poor and their impact on the business.

Businesses now require to play their role in economic and social development based on a "marketing system, which has to design, deliver and make legitimate products and services that enhance the well-being of the population, promoting the equity, fairness and independence of people without harming the traditions "(Dolakia 1988).

Poverty can be described, for some, as a scourge that pervades the world, while it may be an opportunity and an interest in others. In this context, Prahalad (2004) demonstrated that even the successful entrepreneurs and savvy consumers can be affected by poverty .The non-distribution of wealth and capitalism has made poverty a condition which we cannot escape. Therefore, is that poverty can be a factor of growth and development? Or, on the contrary, this is harmful to all economic actors?

For this, it is crucial to know how to harmonize the marketing strategy to better serve our poor clients. Then, How to protect our company facing a phenomenon that we cannot identify in space and time?

This research is used to study the effect of building purpose (consciousness of the price) and emotional factors (atmosphere POS) on the behavioral intention of the poor. Subsequently, we provide managerial implications to support managers and 
marketers to separate predispositions against that consumer.

\section{Conceptual Framework}

\subsection{Poverty}

Poverty is a difficult concept to define and measure. As for Lorenzo (2006), poverty is "no socially acceptable standard of living or inability to reach." The report of the World Bank (2001) on poverty and well-being emphasized two key words in the definition; they are absence and disability. Thus, poverty reflects the lack of control of economic resources (Watts, 1968). This means a lack or absence of income guaranteeing the physiological needs of the individual (food, shelter, and clothing). This definition shows that poverty is attached to the failure of the ability to participate in a society (Sen, 1985). Therefore, poverty can be basic or even complex include freedom, self-respect, social inclusion...

Generally, the operationalization of poverty is based on a single monetary index of living standards (income and expenditure). Nevertheless, the multidimensionality specificity of poverty need integrating several weighted indicators. Thus, the adoption of multidimensionality in the measurement of poverty provides a more realistic assessment of the company investigated.

In fact, the measurement of poverty depends on the space and the time of study. For this reason, there have been several apprehension methods of this concept. Here, we mention the measure developed by the United Nations welfare, considered the most accurate, a multidimensional perspective, is the Human Development Index (HDI).

According to the absolute approach, extreme poverty refers to a situation in which people cannot acquire physiology needs (clean water, proper housing, transportation, sanitation, energy and enough clothing or drugs) that would protect their survival. For this absolute approach, the threshold is set by Seebohm Rowntree (1901), based on a basket of food and non-food needed for daily survival (2400 calories per day for poverty and extreme poverty 1800). However, the United Nations has tended to focus on the elimination of great or extreme poverty. Although, poverty in most EU Member States is generally relative poverty. While the absolute approach is the most used in developed countries such as the United States and Canada.

As for the approach, poverty is determined with respect to the distribution of living standards of the entire population based on the median income. And the median income is the income separating the population into two, that is to say that half of the population has a higher income and half a lower income. The European Union is based on a definition of poverty in relative terms in the country or region where these people strive to live an ordinary life and to participate in economic, social and cultural activities. To do this, European countries have agreed to establish a new standard definition of poverty since 2000. This standard is considered poor persons with resources below the poverty line (less than $60 \%$ of the national median income).

The National Institute of Statistics in collaboration with the African Development Bank and the World Bank poverty rate in Tunisia estimated poverty in Tunisia to be $15.5 \%$ in 2010 against $23.3 \%$ in 2005 and $32.4 \%$ in 2000 , the report on "the extent of poverty, inequality and polarization in Tunisia 2000- 2010" .Stop 2011, the INS adopted a new methodology for measuring poverty based on the data review household surveys (2000, 2005 and 2010) based on the data collected in the National Survey of the budget, consumption and living standards of households conducted in 20102011.L'enquête of the year 2010 focused on a theoretical sample of 13.392 households drawn in a random survey.

The report by a committee of Tunisian academic experts and representatives of government and non-governmental organizations have established a household defined as poor if its consumption is below 
the poverty threshold of 1,277 dinars per year and individuals in major cities against 820 dinars per year per individual in the outside communes.

The extreme poverty rate was $4.6 \%$ in 2010 against extreme poverty rate of $7.6 \%$ in 2005 and $12.0 \%$ in 2000 . The threshold of extreme poverty is set at 757 dinars per year per individual in major cities against 571 dinars per year per person in noncommunal areas.

Thus, in our study we will rely on this source to set the poverty line at 1277 dinars per year per individual, because we are trying to do our study in Tunis capital.

\subsection{Consumer price sensitivity:}

The price is a major factor in the eyes of consumers (Hamelin, 2000; Zollinger, 2004) and for marketing practitioners (Hamelin, 2000; Han, Gupta and Lehmann, 2001; Zollinger, 2004). The price determines the positioning, image and brand loyalty (Desmet and Zollinger, 1997). Similarly, the price affects the balance of the product portfolio and the survival of any for-profit organization.

Pricing is attached to the request. The consumer is both rational; they seek to optimize their financial and emotional resources (Lambin, 1998; Dietsch, BayleTourtoulou et Krémer, 2000). For this, "the challenge for large companies is to make products that make you dream at prices that can pay the poor consumers" (Prahalad, 2004). Furthermore, "the price sensitivity of consumers varies according to national markets, not only in conventional price elasticity terms but also in terms of the use of price as a quality inference variable" (Usunier JC, 2003) .Thus, the perceived value among the poor is a crucial move in the buying process. Desmet P. (1997) defines the concept as "the quality obtained for the price paid and what is received for the sacrifice." This leads to what the intention and actual purchase stimulated by perceived value, referring to the price. To do this, companies must provide "a marketing system which has to design, deliver and make legitimate products and services that enhance the well-being of the population, by promoting fairness, justice and autonomy people without harming the traditions "(Dolakia 1988).

Therefore, the company that targets the poor requires building the capacity to consume its customers "convert the poor consumers is to create markets" (Prahalad, 2004). And it is forced to recover research investments and development by creating a "new price-performance envelope reproducible large-scale" (Prahalad, 2004).

without omitting, the adjustment of offer to the market of the poor, Usunier JC (2003) demonstrated that "creolization, that is to say, local ownership of global properties and their modification or simply reconfiguring the meaning given to them in order to obtain a better fit to the local culture."

Lichtenstein, Ridgway and Netemeyer (1993) created a scale of price sensitivity in both positive and negative features. Regarding our research, we will focus only on the Party considering the negative role of price as a sacrifice indicator and not as an indicator of quality and prestige as our interviewees are poor only. In this scale, the negative role taken is represented through five dimensions, we will hold three as recommended by Hassouna, S. and Krifa, W. (2013), which are:

- Awareness of the value that attaches to the quality / price ratio.

- The sensitivity balances reflect the sensitivity of consumers to buy goods and services when they are on sale.

- Awareness prices are the level of interest of the consumer against low prices.

The other two dimensions related to the negative role of price, that are coupons sensitivity and "price mavenism" have not been included in the measurement scale because sensitivity coupons is integrated into the instrument sensitivity to the 
promotion . Moreover, the dimension of the "price mavenism" involves that a consumer who is sensitive to price should have a very broad knowledge of existing prices (Hassouna, S. and Krifa, W., 2013).

\subsubsection{The awareness of the value}

The study (Hassouna, S. and Krifa, W., 2013) did show awareness of the twodimensional value. The first dimension is related to the search for the lowest prices for the best available products are the price trend (Zeithamel, Z., 1988). The second dimension is more focused on finding the best quality considering the price; it is the quality trend (Lichtenstein, Ridgway and Netemeyer, 1993).

\subsubsection{Sensitivity to the sale}

Hassouna, S. and Krifa, W. (2013) confirmed that sensitivity balances is a two-dimensional variable with a Cronbach's alpha of 0.73 . The first factor focuses on the feeling of having made a good deal, while the second is oriented towards the trend of price/quality ratio.

\subsubsection{Consciousness price}

The first studies of consciousness prices are those of Wells and Tigert (1971). Subsequently, Darden and Perreault (1976) developed multi-scale items with a reliability index of 0.70 . Similarly, the work of Gentry and Dickerson (1983); Barak and Stern (1985/1986); Mittal (1994); Tat and
Bejou (1994); Donthu and Garcia (1999); Donthu and Gilliland (1996) and Kopalle Mullikin and Lindsay (2003) released an alpha of 0.67 , respectively; $0.5 ; 0.69 ; 0.67$; $0.72 ; 0.81 ; 0.86$ and 0.69 . In our present study, we will focus on the latter built price sensitivity, given its importance in the eyes of the poor. In addition, awareness of prices summarizes some of the other factors of an objective influence on the behavioral intention of the consumer.

\subsection{Role of the atmosphere in the behavioral intention of the poor}

The atmosphere POS stands for "all elements of the store that can be controlled in order to influence emotional reactions, cognitive, physiological and / or behavioral occupants (both consumers and employees)" (Rieunier, 2000). Several studies have examined the effect of the atmosphere on consumer the buying behavior in general. As said that those who treated the effects of these atmospheric factors on the behavior of the poor are very few in number. This prompted us to study the effects of the atmosphere on the behavioral intention of the poor.

\subsection{The conceptual model}

The independent variables of our model to be tested are the ambience and design shops that make up the physical and the social dimension atmosphere. The consciousness of the price is the mediating variable between the atmosphere and the behavioral intention of the poor. 


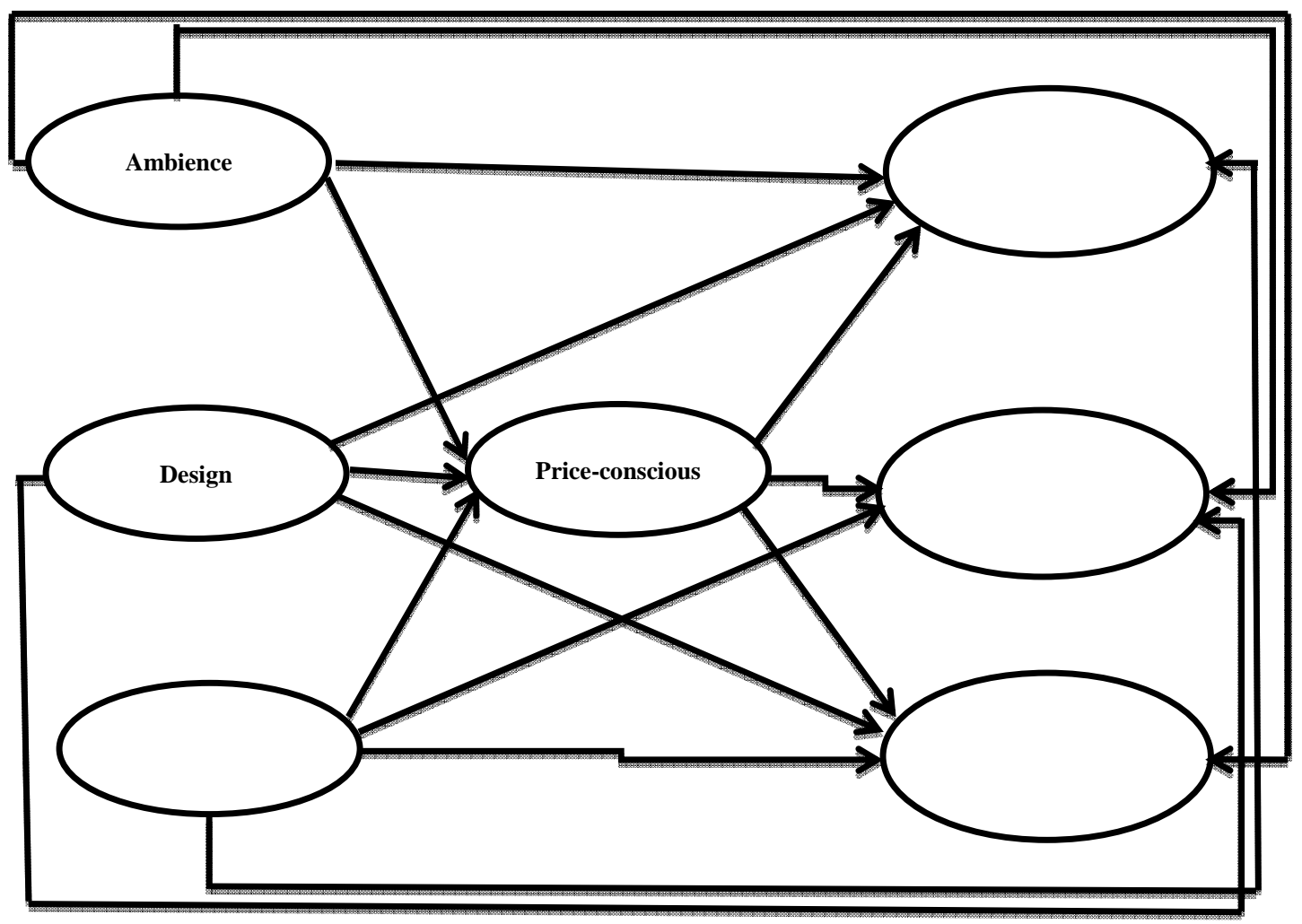

Figure 1: the conceptual model

\subsection{Research Hypotheses}

H1. The atmosphere in the store has a positive effect on the intention to return, the future purchase intention and the intention of the positive word of mouth. (H1.a., H1.b. and H1.c.).

H2. Store design has a positive effect on the intention to revisit the future purchase intention and the intention of the positive word of mouth. (H2.a., H2.b. and H2.c.).

H3. The social atmosphere of the store has a positive effect on the intention to return, the future purchase intention and the intention of the positive word of mouth. (H3.a., H3.b. and H3.c.).

H4. Consciousness price mediates between the atmosphere of the store and the intention to return, the future purchase intention and the intention of the positive word of mouth). (H4.a., H4.b. and H4.c.).
H5. Consciousness price mediates between the store design and the intention to return, the future purchase intention and the intention of the positive word of mouth). (H5.a., H5.b. and H5.c.).

H6. Consciousness price mediates between the social atmosphere of the store and the intention to return, the future purchase intention and the intention of the positive word of mouth. (H6.a., H6.b. and H6.c.).

\section{Methodology and Results}

\section{Sample and data collection}

We conducted our survey of a sample of visitors in the outlets of the popular souk 'Sidi Boumandil'. To do this, we gather the 350 interviewees, poor filter with a question at the beginning of the questionnaire (What is your annual income? It must be less than 1,277 dinars) to provide us with information about their awareness of the price and the degree of the effect of environmental factors. 
Consumers were surveyed in the stores that are available in the popular souk in question. The data collection instrument was the questionnaire. We started our survey by a selection question to continue the investigation only with the poor. The first part offers items related to the scales of measurement concepts of our research as measured by the Likert scale five points. The second part serves to identify the profiles of the interviewees. The final administration of the questionnaire was preceded by a pre-survey of 30 individuals in our target population (the poor). The test questionnaires were designed to amend misunderstood terms.

\section{Choice of measuring instruments}

\subsection{The atmosphere}

Regarding this work, we adopt the scale of measurement of the atmosphere of the sale point created by Lemoine and Plichon (2000).

Table 1 : Scale of the store atmosphere

\begin{tabular}{|c|c|}
\hline & Store atmosphere \\
\hline \multirow{4}{*}{ ambience } & - The background music is: Pleasant -3 -2 -1 0123 Unpleasant \\
\hline & - The Light: Pleasant -3 -2 -1 0123 Unpleasant \\
\hline & - Acoustics is: quiet Store $-3-2-10123$ noisy Store \\
\hline & $\begin{array}{l}\text { - In the shop there are too many customers }-\begin{array}{llllllll}-3 & -2 & -1 & 0 & 1 & 2 & 3 & \text { Not enough } \\
\text { customers }\end{array}\end{array}$ \\
\hline \multirow{5}{*}{ Design } & - The Size of the store is: Unpleasant -3 -2 -10 0123 Pleasant \\
\hline & - The store is: Misplaced $-3-2-101233$ Tidy \\
\hline & - the Displacement in the store is: Easy bad -3 -2 -1 0123 Easy \\
\hline & - its Store is: No practice $-3-2-10123$ Practice \\
\hline & - The Products are: hard to find $-3-2-10123$ Easy to find \\
\hline \multirow{4}{*}{ Social } & - The Employees: \\
\hline & Do not seem friendly $-3-2-10123$ friendly look \\
\hline & Do not seem helpful -3 -2 -1 0123 seem helpful \\
\hline & Do not seem available $-3-2-10123$ appear available \\
\hline
\end{tabular}

This scale includes three dimensions of the atmosphere which are: environmental factors, design factors and social factors. The reliability of each of the three dimensions is good (alpha 0.71 , respectively, 0.76 and 0.84 ).

\subsection{Prices' consciousness}

In our present study, we will retain the scale of prices' consciousness developed by Ofir (2004) that was been inspired from the work of Lichtenstein, Ridgway and Netemeyer (1993).

Table 2: Measuring the range of consciousness price

\begin{tabular}{|l||}
\hline \multicolumn{1}{|c|}{ Consciousness price } \\
\hline \hline I'm not willing to make an extra effort to find the lowest prices. \\
\hline \hline I would go to more than one store to take advantage of low prices. \\
\hline \hline The money saved by seeking low prices is not usually the time and effort provides. \\
\hline I would never go to several stores to find lower prices. \\
\hline Time lost to find low price is usually not worth it \\
\hline
\end{tabular}


This scale has a good reliability of 0.85 and was confirmed and purified by five items (Hassouna, S. and Krifa, W., 2013).

\subsection{The behavioral intention}

This construct is measured by 3 Measuring instruments as recommended by Benhamza, Z. (2008), as shown in the following table:

Table 3: Measuring range of behavioral intention

\begin{tabular}{|c|l|}
\hline \multicolumn{2}{|c|}{ Behavioral intentions } \\
\hline \multirow{2}{*}{ Word of mouth } & - I tell the other positive things about X. \\
\cline { 2 - 3 } & - I recommend X to someone looking for a board. \\
\cline { 2 - 3 } & - I encourage my friends to go to X. \\
\hline \multirow{2}{*}{ Intention to return } & $\begin{array}{c}\text { - What is the probability that you return to X? } \\
\text { (Scale from very unlikely to very like. }\end{array}$ \\
\hline $\begin{array}{c}\text { Future purchase } \\
\text { intent }\end{array}$ & $\begin{array}{c}\text { - I intend to buy again something I saw today in this store. } \\
\text { (Scale from not at all disagree to strongly agree). }\end{array}$ \\
\hline
\end{tabular}

- The word of mouth intention of scale was developed by Zeithaml V., Berry L.L. and Parasuraman A. L. L. (1997) and validated in the context of a place of sale by Bloemer and Schroeder (2002). The reliability of this scale is good with an alpha of 0.92 .

- The revisit intention scale Boulding W. A., Kalra, R. and Staelin Zeithaml V. (1993) reflects the probability to revisit the store through a semantic scale of the very unlikely to very likely.

- The single-item scale of future purchase intent, Rieunier (2000), where the interviewee expresses the degree of agreement or disagreement to buy again something he spotted in the visit he has just made.

\section{The Results}

\subsection{The reliability analysis}

The exploratory analysis through the ACP and the Cronbach's alpha and the Rho Jöreskog allowed us to check the reliability of our measuring instruments. The following table shows Cronbach's Alpha and Rho Jöreskog for each measurement scale.

Table 4: The reliability of the measurement scales

\begin{tabular}{|c|c|c|c|c|c|c|}
\hline $\begin{array}{c}\text { Measurement } \\
\text { scales }\end{array}$ & Dimensions & KMO & $\begin{array}{c}\text { Bartlett's } \\
\text { test }\end{array}$ & $\begin{array}{c}\text { \% of the } \\
\text { conserve } \\
d \\
\text { variance }\end{array}$ & $\begin{array}{c}\text { Cronbach's } \\
\text { alpha }\end{array}$ & $\begin{array}{c}\text { Rho } \\
\text { Jöresko } \\
\text { g }\end{array}$ \\
\hline \multirow{3}{*}{$\begin{array}{c}\text { Store } \\
\text { atmosphere }\end{array}$} & Ambience & \multirow{3}{*}{0,810} & \multirow{3}{*}{0,000} & 41,421 & 0,985 & 0,873 \\
\hline & Design & & & 29,852 & 0,994 & 0,912 \\
\hline & Social & & & 26,263 & 0,994 & 0,917 \\
\hline $\begin{array}{c}\text { Consciousnes } \\
\text { s prices }\end{array}$ & $\begin{array}{l}\text { Consciousness } \\
\text { prices }\end{array}$ & 0,918 & 0,000 & 86,405 & 0,961 & 0,859 \\
\hline
\end{tabular}




\begin{tabular}{|c|c|c|c|c|c|c|}
\hline \multirow{3}{*}{$\begin{array}{c}\text { Behavioral } \\
\text { intention }\end{array}$} & $\begin{array}{l}\text { Intention to } \\
\text { return }\end{array}$ & \multirow{3}{*}{0,810} & \multirow{3}{*}{0,000} & \multirow{3}{*}{68,051} & \multirow{3}{*}{0,858} & \multirow{3}{*}{0,798} \\
\hline & $\begin{array}{l}\text { Future } \\
\text { purchase intent }\end{array}$ & & & & & \\
\hline & $\begin{array}{l}\text { Positive word } \\
\text { of mouth } \\
\text { intention }\end{array}$ & & & & & \\
\hline
\end{tabular}

Thus, these indices confirm the reliability of all scales of our model.

\subsection{The adequacy of the research model}

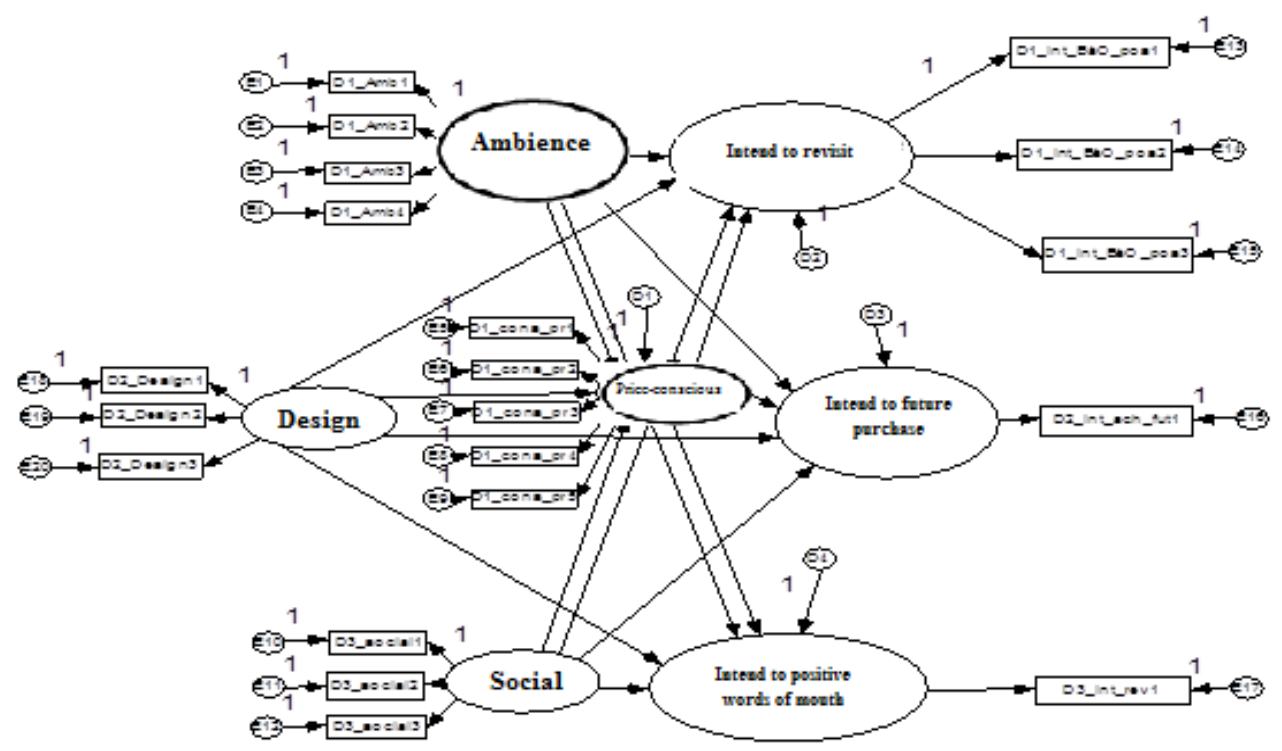

Figure 2: The structural model

Table 5: Adjustment Indices of global structural model

\begin{tabular}{|l|l|l|l|l|l|l|l|c|}
\hline$\chi^{2}$ & $\chi^{2} / \mathbf{d l}$ & GFI & AGFI & NFI & CFI & PNFI & PCFI & RMSEA \\
\hline 580,785 & 4,537 & 0,797 & 0,729 & 0,939 & 0,952 & 0,785 & 0,796 & 0,119 \\
\hline
\end{tabular}

Therefore, we approve the good fit of our research model because the indices presented in the table significantly verify the acceptance thresholds.

\subsection{Hypotheses' verification}

After testing the quality of the model fit, we check the assumptions of our present research. In order to estimate the causal relationships of the model, we adopt the maximum likelihood method in our structural analysis in Amos.

\subsubsection{Verification of hypotheses on the direct effect}

Significant relationships are those having the values of Student (CR) greater than $1.96(\mathrm{p}<0.05)$. 
Table 6: Checking the direct effect

\begin{tabular}{|c|c|c|c|c|}
\hline Hypotheses & Relations & CR & $\mathbf{P}$ & Résultats \\
\hline $\begin{array}{l}\text { H1.: } \\
\text { H1.a. } \\
\text { H1.b. } \\
\text { H1.c. }\end{array}$ & $\begin{array}{l}\text {-Revisit intention <--- Atmosphere } \\
\text { - Future purchase intention <--- Atmosphere } \\
\text { - Positive word of mouth Intention <--- } \\
\text { Atmosphere }\end{array}$ & $\begin{array}{l}2,367 \\
0,345 \\
3,395\end{array}$ & $\begin{array}{l}0,003 \\
\text { NS } \\
0,000\end{array}$ & $\begin{array}{l}\text { H1.a. } \\
\text { Confirmed } \\
\text { H1.b. } \\
\text { Infirmed } \\
\text { H1.c. } \\
\text { Confirmed }\end{array}$ \\
\hline $\begin{array}{l}\text { H2.: } \\
\text { H2.a. } \\
\text { H2.b. } \\
\text { H2.c. }\end{array}$ & $\begin{array}{l}\text {-Revisit intention <-- Design } \\
\text { - Future purchase intention <--- Design } \\
\text { - Positive word of mouth Intention <- Design }\end{array}$ & $\begin{array}{l}3,897 \\
0,345 \\
7,845\end{array}$ & $\begin{array}{l}0,004 \\
\mathrm{NS} \\
0,000\end{array}$ & $\begin{array}{l}\text { H2.a. } \\
\text { Confirmed } \\
\text { H2.b. } \\
\text { Infirmed } \\
\text { H2.c. } \\
\text { Confirmed }\end{array}$ \\
\hline $\begin{array}{l}\text { H3.: } \\
\text { H3.a. } \\
\text { H3.b. } \\
\text { H3.c. }\end{array}$ & $\begin{array}{l}\text {-Revisit intention <--- Social } \\
\text { - Future purchase intent <--- Social } \\
\text { - Positive word of mouth intention <--- Social }\end{array}$ & $\begin{array}{l}1,097 \\
0,345 \\
3,014\end{array}$ & $\begin{array}{l}\text { NS } \\
\text { NS } \\
0,003\end{array}$ & $\begin{array}{l}\text { H3.a. } \\
\text { Infirmed } \\
\text { H3.b. } \\
\text { Infirmed } \\
\text { H3.c. } \\
\text { Confirmed }\end{array}$ \\
\hline
\end{tabular}

Only the H1.a. Hypotheses H1.c., H2.a., H2.c.et H3.c. are confirmed at the 5\% level. Subsequently, we consider testing the mediating effect of the consciousness of the price.

\subsubsection{The mediating effect of} consciousness prices verification

The test conditions Baron and Kenny (1986) lead us to test the mediating effect of consciousness at a price between the POS atmosphere and the behavioral intention at the $5 \%$ level.

Table 7: Checking the mediating effect

\begin{tabular}{|c|c|c|}
\hline Hypotheses & Relations & The validated hypotheses \\
\hline $\begin{array}{l}\text { H4.: } \\
\text { H4.a. } \\
\text { H4.b. } \\
\text { H4.c. }\end{array}$ & 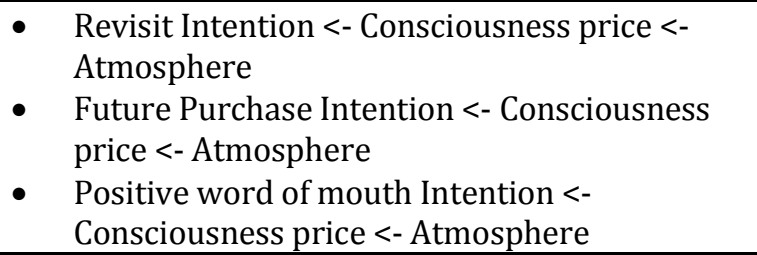 & $\begin{array}{ll}\text { - } & \text { H1.a. confirmed } \\
\text { (Partial mediation) } \\
\text { - } \\
\text { H1.b. confirmed } \\
\text { (Partial mediation) } \\
\text { H1.c. confirmed } \\
\text { (Partial mediation) }\end{array}$ \\
\hline $\begin{array}{l}\text { H5.: } \\
\text { H5.a. } \\
\text { H5.b. } \\
\text { H5.c. }\end{array}$ & $\begin{array}{ll}\text { - } & \text { Revisit Intention <- Consciousness price <- } \\
\text { Design } \\
\text { - } \\
\text { Future Purchase Intention <--- Consciousness } \\
\text { price <- Design } \\
\text { Positive word of mouth Intention <--- } \\
\text { Consciousness price <- Design }\end{array}$ & $\begin{array}{l}\text { - } \quad \text { H2.a. confirmed } \\
\text { (Partial mediation) } \\
\text { H2.b. confirmed } \\
\quad \text { (Partial mediation) } \\
\text { H2.c. confirmed } \\
\text { (Partial mediation) }\end{array}$ \\
\hline
\end{tabular}




\begin{tabular}{|l|ll|c|}
\hline H6. : & $\bullet$ & Revisit Intention <--- Consciousness Price <- & $\bullet$ H3.a. infirmed \\
H6.a. & Social \\
H6.b. & $\begin{array}{l}\text { Future Purchase Intention <--- Consciousness } \\
\text { H6.c. }\end{array}$ & $\begin{array}{l}\text { Price <- Social } \\
\text { Positive word of mouth Intention <--- } \\
\end{array}$ & $\begin{array}{l}\text { Consciousness Price <- Social } \\
\text { (Partial mediation) }\end{array}$ \\
\hline
\end{tabular}

The analysis of the mediation of consciousness price leads us to confirm the hypotheses in $\mathrm{H} 1$ and $\mathrm{H} 2$. While the sub hypotheses H3.a. and H3.b. are overturned and H3.c. is confirmed.

\subsubsection{Discussion of the results and contributions of research}

The store's atmosphere promotes the positive word of mouth visitors with their surroundings, friends, family.... Mediation of consciousness price between the atmosphere POS (atmosphere, design and social) and the intention to the positive word of mouth is partial. This says the positive role of a suitable atmosphere on the transfer of information from visitors is favorable to the potential consumers' point of sale.

Thus, pleasant background music that kills the annoying noise, crowds creating an animation sought by the visitor and a cheerful and relaxing light in the point of sale are the stimulants of the positive word of mouth.

In addition, the layout of the store, the arrangement references, the ease of finding articles, the easy movement in the retail space significantly affect the positive word of mouth visitor stores in the souk.

Without omitting the crucial role of vendors in these outlets intended primarily to the poor. Thus, the warm welcome, the courtesy, the friendliness and the sympathy of vendor are the shop's success pillars. Visitors in general and especially the poor seeking to find a private seller and confident may advise, negotiate, discuss, serve his prospect in real time and give him consideration and interest.

In fact, the poor are not only tied to the price. These potential consumers of popular stores enjoy the pleasant atmosphere. The visit of outlets located in the souk in question is, in addition to the acquisition of the items, a walk. Visiting these outlets is an opportunity to experience pleasant moments, share feelings with loved ones. Points of sale in the souk are friendly, nostalgic and intimate. Sometimes we see visits from these outlets tied to events (school year, wedding or El Eid) to purchase items at great prices with acceptable quality.

The poor are rational and prefer to do good business with such popular outlets. They seek to satisfy their needs under stress on a budget. Nevertheless, the poor can be emotional as the rich. Moreover, the poor can be more sensitive to store' atmospheric factors than wealthy.

To this end, store' managers should gratify the different atmospheric factors (atmosphere, design and social) to take advantage of the opportunity of the visit in order to convert visitors into sales, which conveys a good image and a good reputation from the point of sale. Similarly, POS makers have an interest in bettering the position of their shops and the souk in general in the eyes of their customers by creating a pleasant atmosphere, an arrangement with various choices and comparative advantage and an active and kindly sellers.

Moreover, the atmosphere and POS design have a significant effect on the intention to return customers. This leads sellers to focus on sensory factors (light, music, crowd, perfume ...) that attract customers to patronize their spaces. Similarly, the design of the POS atmosphere allows rising revisits customers. The architecture and good spatial planning to facilitate free movement, to find that we are looking for the easy hit, easy fitting, and the diversification and fair presentation of the offer are mobile revisit POS. 
The analysis of the mediating effect of consciousness prices shows us that mediation is validated between the physical atmosphere (the atmosphere and design) and the future purchase of the visitors. This means that the customer is looking for an affordable price and wants to enjoy buying cheaper references; he prefers a more pleasant and attractive point of sale.

\section{Conclusion}

This study allows us to infer that the physical and social atmosphere significantly affect the intent of the positive word of mouth and the intention to revisit the point of sale. However, the future purchase intention always refers to prices for the poor. The social atmosphere has no significant effect on the future purchase intention for the poor. Only the physical atmosphere can affect the future purchasing for the poor, but by mediation of the total price. In fact, the atmosphere cannot promote the future purchase intent without ensuring the right price. The atmosphere cannot override the price for the poor.

\section{References}

1. WORLD BANK (2001), Poverty Manual (chapter 1: The Concept of Poverty and Well-Being).

2. BARAK, B. and STERN, B. (1985/1986), Women's age in advertising: An examination of two consumer age profiles, Journal of Advertising Research, $25,38-47$.

3. BARON, R.and KENNY, D.(1986), The moderator-mediator variable distinction in social psychological research: conceptual, strategic and statistical considerations, Journal of Personality and Social Psychology, 51 (6), 1173-1182.

4. BENHAMZA, Z. (2008), La valeur perçue de l'expérience de butinage et satisfaction du butineur: antécédents et conséquences, Thèse de l'université Paris I Panthéon Sorbonne, Paris.
5. BERRY, L.and PARASURAMAN, A. (1997), Listening to the customer - the concept of a service quality information system, Sloan Management Review, 38 (3), 65-76.

6. BLOEMER, J. and ODKERKEN, S. (2002), Store satisfaction and store loyalty explained by customer- and storerelated factors, Journal of Consumer Satisfaction, Dissatisfaction and Complaining Behavior, 15, 68-80.

7. BOULDING, W., KALRA, A., STAELIN, R. and ZEITHAML, V. (1993), A dynamic process model of service quality: from expectations to behavioural intentions, Journal of Marketing Research, 30, 7-27.

8. DARDEN, W. and PERREAULT, J. (1976), Identifying Interurban Shoppers: Multi product Purchase Patterns and Segmentation Profiles, Journal of Marketing Research, 13, 51- 60.

9. DESMET, P. and ZOLLINGER, M. (1997), Le prix : De l'analyse conceptuelle aux méthodes de fixation, (Ed), Economica, Paris.

10.DICKERSON, M. and GENTRY, J. (1983), Characteristics of Adopters and NonAdopters of Home Computers, Journal of Consumer Research, 10 (6), 225-235.

11.DIETSCH, M., BAYLE, T. and KREMER, F. (2000), Les déterminants de l'élasticité prix des marques, Recherche et Applications Marketing, 15, (3), 43-53.

12.DONTHU, N. and GARCIA, A. (1999), The Internet Shopper, Journal of Raju, $P$ Advertising Research, 39, (3), 52-58.

13.DONTHU, N. and GILLIAND, D. (1996), The Infomercial Shopper, Journal of Advertising Research, 36, (2), 69-76.

14.DHOLAKIA, R., SHARIF, M. and BHADARI, L. (1988), Consumption in the third World: Challenges for Marketing and Economic Development, In: KUMCU, E.et FIRAT, A. (Eds.), Marketing and development: Toward broader dimensions; Research in Marketing, 
Supplement 4, Greenwich, CT: JAI Press, $129-147$.

15.HASSOUNA, S. and KRIFA, W. (2013), cours Marketing, [Online]. [Date of accessed. 10/09/2014]. http://marketing.thus.ch/loader.php?p age $=$ Krifa-IV.

16. KOPALLE, Praveen K. and LINDSEYMULLIKIN, J. (2003), The Impact of External Reference Price on Consumer Price Expectations, Journal of Retailing, 79, (4), 225-236.

17.LAMBIN, J. (1998), le marketing stratégique : du marketing à l'orientation marché, 4ème Edition, (Ed), science International, Paris, France.

18.LICHTENSTEIN, D., RIDGWAY, N. and NETEMEYER, R. (1993), Scale related to pricing perception, Handbook of Marketing, 271-272.

19.LEMOINE, F. and PLICHON, V. (2000), Le rôle des facteurs situationnels dans l'explication des réactions affectives du consommateur à l'intérieur d'un point de vente, Actes 16ème du Congrès International de l'Association Française du Marketing, Montréal.

20.LORENZO, G. (2006), Impacts des politiques sur la pauvreté Définition de la pauvreté Service de soutien aux politiques agricoles, Division de l'assistance aux politiques, FAO, Italie Paolo Liberati, Université d'Urbino, «Carlo Bo», Institut d'Economie, Urbino, Italie pour Organisation des Nations Unies pour l'alimentation et l'agriculture.

21. [Online]. Publisher. FAO. [20/09/2014]. Available:

http://www.fao.org/tc/easypol.

22. The report on, la mesure de la pauvreté, des inégalités et de la polarisation en Tunisie 2000-2010, established by the National Institute of Statistics in collaboration with the African Development Bank and the World Bank.
23. MITTAL, B. (1994), An integrated framework for relating diverse consumer characteristics to supermarket coupon redemption, Journal of Marketing Research, 31, 533544.

24.RIEUNIER, S. (2000), L'influence de la musique d'ambiance sur le comportement du consommateur sur le lieu de vente, Thèse de Doctorat en Sciences de Gestion, Université Paris IX Dauphine.

25.SEN, A. (1985), Well-being, agency and freedom, Journal of Philosophy, 82 (4), 169-221.

26. TAT, P. K. and BEJOU, D. (1994), Examining black consumer motives for coupon usage, Journal of Advertising Research, march-April, 29-35.

27.PRAHALAD, C. (2004), 4 milliards de nouveaux consommateurs: vaincre la pauvreté grâce au profit, (Ed), Village mondial, Paris.

28.PRIME, N. and USUNIER, J. (2004), Marketing International: Développement des Marchés et Management Interculturel. 2 ${ }^{\text {nd }}$ Edition, Vuibert Bookstore, Paris.

29.WATTS, H.(1968), An economic definition of poverty, in Moynihan D. P. (ed.), On Understanding Poverty, Basic Books, New York, USA.

30.WELLS, W. and DOUGLAS, J. (1971), Activities, interests, and opinions, Journal of Advertising Research, August, 11, 27-35.

31.ZEITHAMEL, Z. (1988), Consumers perceptions of price quality and value: a means end model and synthesis of evidence, Journal of Marketing, 52, July, $2-22$.

32.ZEITHAML, V., BERRY, L. and PARASURMAN, A. (1996), The behavioural consequences of service quality, Journal of Marketing, 60, 31-46. 